\title{
The diet of otters (Lutra lutra) on the Agri river system, one of the most important presence sites in Italy: a molecular approach
}

\author{
Maria Buglione ${ }^{1}$, Simona Petrelli ${ }^{1}$, Claudia Troiano ${ }^{2}$, Tommaso Notomista ${ }^{1}$, Eleonora Rivieccio ${ }^{1}$, Domenico \\ Fulgione ${ }^{\text {Corresp. } 1}$ \\ ${ }^{1}$ Department of Biology, University of Naples Federico II, Naples, Italy, Italy \\ Department of Humanities, University of Naples Federico II, Naples, Italy, Italy \\ Corresponding Author: Domenico Fulgione \\ Email address: fulgione@unina.it
}

Background. The Eurasian otter (Lutra lutra) underwent a strong decline in large areas of the CentralWestern part of its distribution range, during the second half of the twentieth century. In Italy, only residual fragmented nuclei survive in the Central-Southern part of the peninsula. Nowadays, the otter is one of the most endangered mammals in Italy, and increasing the knowledge about the ecology of this species is a key step in defining fitting management strategies. Here we provide information about the diet of otter on the Agri river system, one of the most important presence sites in Italy, to understand both the species' food requirements and the impact on fish communities.

Methods. DNA metabarcoding and High Throughput Sequencing were used on DNA extracted from spraints. We amplified DNA with a primer set for vertebrates, focusing efforts on the bulk of the otter's diet (fishes and amphibians).

Results. Our findings showed that the diet of the otter was dominated by cyprinids (97.77 \%, and $99.14 \%$ of fishes), while amphibians represented $0.85 \%$ of the sequences analyzed. Results are in general accordance with previous studies based on morphological characterization, however molecular analyses allow to resolve some morphological uncertainties. Although the study area offers a very wide range of available prey, the diet of the otters shows marked selectivity. We highlighted a variation in prey consumed, in accordance with the typology of water system (i.e. river, lake, tributary). Some of the preys found in the diet were alien species introduced by man for sport fishing. Our findings could help define strategies useful for the conservation of the otter population in Southern Italy, suggesting management actions directed at avoiding fish community alterations through illegal stockings without severe controls on their taxonomic status. These introductions could result in a general reduction in the diversity of the otter's preys, affecting its predatory behavior. 
1 The diet of otters (Lutra lutra) on the Agri river system, one of the most important presence

2 sites in Italy: a molecular approach

3

4 Maria Buglione $^{1}$, Simona Petrelli ${ }^{1}$, Claudia Troiano $^{2}$, Tommaso Notomista $^{1}$, Eleonora Rivieccio ${ }^{1}$

5 and Domenico Fulgione ${ }^{1}$

6

$7{ }^{1}$ Department of Biology, University of Naples Federico II, Via Cinthia, 28, 80126, Naples, Italy

$8 \quad{ }^{2}$ Department of Humanities, University of Naples Federico II, Via Porta di Massa 1, 80133

9 Naples, Italy

10

11

12 Corresponding author:

13 Domenico Fulgione

14 Department of Biology, University of Naples Federico II, Via Cinthia 26, 80126 Naples, Italy

15 E mail address: fulgione@unina.it

16 


\section{Abstract}

18 Background. The Eurasian otter (Lutra lutra) underwent a strong decline in large areas of the

19 Central-Western part of its distribution range, during the second half of the twentieth century. In

20 Italy, only residual fragmented nuclei survive in the Central-Southern part of the peninsula.

21 Nowadays, the otter is one of the most endangered mammals in Italy, and increasing the

22 knowledge about the ecology of this species is a key step in defining fitting management

23 strategies. Here we provide information about the diet of otter on the Agri river system, one of

24 the most important presence sites in Italy, to understand both the species' food requirements and

25 the impact on fish communities.

26 Methods. DNA metabarcoding and High Throughput Sequencing were used on DNA extracted

27 from spraints. We amplified DNA with a primer set for vertebrates, focusing efforts on the bulk

28 of the otter's diet (fishes and amphibians).

29 Results. Our findings showed that the diet of the otter was dominated by cyprinids $(97.77 \%$, and

$3099.14 \%$ of fishes), while amphibians represented $0.85 \%$ of the sequences analyzed. Results are in

31 general accordance with previous studies based on morphological characterization, however

32 molecular analyses allow to resolve some morphological uncertainties. Although the study area

33 offers a very wide range of available prey, the diet of the otters shows marked selectivity. We

34 highlighted a variation in prey consumed, in accordance with the typology of water system (i.e.

35 river, lake, tributary). Some of the preys found in the diet were alien species introduced by man

36 for sport fishing.

37 Our findings could help define strategies useful for the conservation of the otter population in

38 Southern Italy, suggesting management actions directed at avoiding fish community alterations

39 through illegal stockings without severe controls on their taxonomic status. These introductions 
40 could result in a general reduction in the diversity of the otter's preys, affecting its predatory

41 behavior.

42

43

Introduction

44 The Eurasian otter (Lutra lutra) is a semi-aquatic carnivore widespread in freshwater habitats of

45 Europe and Asia. During 1960 - 1968, the species underwent a strong decline in large areas of

46 the Central-Western part of its distribution range (Mason \& Macdonald, 1986; Mason \&

47 Macdonald, 1994; Conroy \& Chanin, 2000; Hilton-Taylor, 2000; Conroy \& Chanin, 2002)

48 mainly due to human persecution, persistent organic pollutants, loss of riparian habitats (Mason,

49 1995; Murk et al., 1998; Mason \& Wren, 2001; Ruiz-Olmo et al., 2002; Panzacchi, Genovesi \&

50 Loy, 2010) and fish community alterations as a result of over-fishing (Arcà \& Cassola, 1986;

51 Carss, 1995).

52 In Italy, this severe decrease led to the total disappearance of the otter in the Northern part of the

53 peninsula (Macdonald \& Mason, 1983; Cassola, 1986; Macdonald \& Mason, 1994; Prigioni,

54 Balestrieri \& Remonti, 2007) and to a gradual decline in Central and Southern Italy (Spagnesi,

55 2002; Boitani, Lovari \& Vigna Taglianti, 2003; Prigioni, Balestrieri \& Remonti, 2007), with

56 residual fragmented populations mainly in Basilicata, Campania and Calabria regions (Prigioni,

57 1997).

58 At present, the Southern-Italian population, geographically and genetically isolated from all otter

59 populations living in Europe (Spagnesi, 2002; Randi et al., 2003), occurs in a continuous range

60 from Abruzzo to Basilicata, Calabria and Apulia (Giovacchini, Marrese \& Loy, 2018). Despite a

61 general positive trend and a slow recovery with an expansion northward (Fusillo, Marcelli \&

62 Boitani, 2003; De Castro \& Loy, 2007; Prigioni, Balestrieri \& Remonti, 2007; Balestrieri et al., 
63 2008; Loy et al., 2009; M Buglione et al., 2020, unpublished data), the otter in Italy is one of the

64 most threatened mammals, listed as Endangered (EN, category D) on the Official Italian Red List

65 (Loy et al., 2010; Rondinini et al., 2013; Scorpio et al., 2014), both at national and local levels.

66 In this scenario, increasing the knowledge about the ecology of the species is a key step in

67 understanding factors impacting this population, in order to better define fit management

68 strategies.

69 We focused our study on a very important presence site of the otter in Italy, the Agri river system

70 (in the Basilicata region), which flows through the internal part of Southern Italy up to the Ionian 71 Sea.

72 This river system hosts one of the main, stable otter populations (Prigioni et al., 2006b), and its

73 upper course represents a precious connection between the otter populations of different regions

74 in Southern Italy (Campania, Basilicata and Calabria) (Smiroldo et al., 2009).

75 The Basilicata region accounts, together with the Campania region, for more than $70 \%$ of the 76 species' range (Prigioni et al., 2005), which spans an area between Naples and the Ionian Sea.

77 The latest survey reports an estimated otter population for the entire Agri basin (237 km) of 43 -

7847 individuals (Prigioni et al., 2006b). Given the cumulative length of the watercourses we

79 monitored $(136 \mathrm{~km})$, there are approximately 25 individuals in the study area.

80 Here, we provide data on otter diet diversity for the population of the Agri system, obtained via

81 DNA metabarcoding and High Throughput Sequencing (HTS) analysis on DNA extracted from

82 spraints.

83 We collected spraints in five sample sites which included both the main river and its tributaries,

84 as well as an artificial lake. All these represent diverse freshwater habitats which could influence

85 the composition of the otter's diet differently. 
86 Moreover, exploring the putative variation, in light of food availability, could reveal taxonomic

87 entities (among the preys) that are difficult to collect with direct methods focusing on fish

88 communities. This information is of great importance, mainly considering the current habitat

89 modifications and ecosystem alterations that might induce unpredictable changes in abundance,

90 diversity, or availability of resources relevant for this animal (Sanderson et al., 2002; Thuiller et

91 al., 2011). The impact of new alien species could be significant (Prigioni et al., 2006a), so

92 investigating the role of native versus exotic species in the otter's diet could also provide useful

93 information about possible alterations of predatory behavior.

\section{Material and methods}

96 Study area

97 The study was performed on the upper course of the Agri river flowing in the Basilicata region $98\left(40^{\circ} 17^{\prime} \mathrm{N}-15^{\circ} 58^{\prime} \mathrm{E}\right.$, Southern Italy; Fig. 1).

99 The Agri river's source is located on Monte Maruggio, Lucan Apennines at the North of Monte

100 Volturino. Along its course, the Agri river is enriched by various tributaries. Torrential flow

101 characterizes most of its watercourses, which are forced to reduce their speed at downstream

102 reaches, where the Agri river is dammed, creating the Pietra del Pertusillo lake. This artificial

103 lake is located on Grumento Nova, Montemurro e Spinoso territories and consists of an area of

$1047.5 \mathrm{~km}^{2}$ with a maximum capacity of 150 million cubic meters of water. The entire area falls

105 within the Appennino Lucano and Val d'Agri-Lagonegrese National Park. Proceeding toward the

106 East, the Agri river further widens its riverbed, flowing in a pattern of intertwined canals, typical

107 of a Fiumara of Southern Italy. Finally, it flows into the Ionian Sea with a small estuary (Gulf of

108 Taranto). 
109 The study area covers a land in which rivers cross very different environments in a state of

110 brook, mature river and even lake. This environmental diversity greatly affects the availability of

111 prey for the otter, which, according to current literature, could feed on aquatic animals, such as

112 fishes, amphibians and crustaceans, as well as terrestrial animals, such as reptiles, or on remains

113 of mammals and birds (Clavero et al., 2003).

114 The fish assemblages of the Agri basin are mainly those of the Central Peri-Mediterranean region 115 (BR2 in Reyjol et al., 2008), dominated by cyprinids and trout. More in detail, the recent Fish

116 Plan Management of the Basilicata region (Caricato et al., 2014) drafted the regional fish map

117 highlighting the presence of endemisms, such as Alburnus alburnus, Barbus plebejus, Squalius

118 squalus, Tinca tinca, and allochthonous species from other Italian regions (i.e. Alburnus

119 alborella, Salmorutilus rubilio, Scardinius erythrophthalmus, Salmo trutta) and Asiatic regions

120 (i.e. Carassius carassius, Carassius auratus, Cyprinus carpio, Esox lucius, Rutilus rubilio)

121 (Prigioni et al., 2006a; Caricato et al., 2014).

122 Furthermore, quantitative information about fish assemblages in the Agri river provided by an

123 electro-fishing census (Prigioni et al., 2006a), showed that, considering a total of 180 fish

124 caught, Barbus plebejus, Barbus meridionalis (30.0\%) and Rutilus rubilio (27.8\%) were the most

125 abounded fish species, followed by Alburnus arborella and Alburnus albidus (12.8\%), Salmo

126 trutta (11.1\%), Micropterus salmoides (11.1\%), Leuciscus cephalus (5.6\%) and Lepomis

127 gibbosus (1.6\%).

128 Some introduced fishes (i.e. Micropterus salmoides and Lepomis gibbosus) replaced the native

129 fauna at the confluences of the Agri and Maglie rivers with the Pietra del Pertusillo lake, in

130 which these exotic fish species are very common (Prigioni et al., 2006a). 
131 Among amphibians, reported species are Bombina pachypus, Bufo bufo, Bufo balearicus, Rana

132 italica, Pelophylax synkl.hispanicus and Lissotriton italicus (Romano et al., 2012).

\section{Sample collection}

135 Sampling was performed from May to December 2018, authorized by Ente Parco Nazionale

136 dell'Appennino Lucano, Val d'Agri-Lagonegrese. A team of collectors walked along transects of

137 approximately $5 \mathrm{~km}$, checking both riversides of the watercourses, rocks and structures emerging

138 from the water, searching for otter scats (spraints).

139 Field activities determine the success of genetic analysis. In fact, old samples or bad preservation

140 affect the degradation of nucleic acids (Taberlet et al., 1996; Dallas et al., 2000; Goossens et al.,

141 2000; Jansman et al., 2001). Therefore, we only collected fresh spraints ( $\mathrm{N}=51$, scats $<2$ day

142 old), the freshness of which was determined by skilled field operators using odor and aspect

143 patterns. Old spraints were removed the day before each sampling session, with collection taking

144 place the following day in the early morning, to reduce the time interval from defecation to

145 collection. Furthermore, all scats were manipulated with sterilized tools and the samples were

146 placed in a sterile tube together with silica granules to speed up drying (Wasser et al., 1997;

147 Buglione et al., 2020).

148 Each record was geo-referenced using a global positioning system (GPS; UTM-WSG 84) and

149 loaded in a GIS environment using QGIS 3.4.2 (Fig. 1).

150

151 Diet analysis

152 DNA extraction 
153 In order to prevent potential contamination, all genetic analyses were performed in a dedicated

154 laboratory used exclusively for environmental DNA processing. Total genomic DNA was

155 extracted from spraints using QIAamp DNA Fast Stool Mini Kit (QIAGEN, Valencia, CA),

156 following manufacturer's guidelines. All experiments were performed including a negative

157 control to check for potential cross-contaminations. The performance of the process was

158 evaluated using 1\% agarose gel electrophoresis in buffer TBE 1X, while purity and concentration

159 of extracted DNA were checked using a Nanodrop ND-2000 (Nanodrop, Wilmington, DE, USA)

160 and a Qubit Fluorometer 3.0 (Invitrogen by Thermo Fisher Scientific), respectively.

161

162 Selection of the molecular marker

163 According to previous studies that analyzed the diet of the otter using a morphological approach,

164 fishes and amphibians formed the bulk of the otter's diet (Prigioni et al., 2006a; Remonti et al.,

165 2008; Balestrieri, Remonti \& Prigioni, 2009; Smiroldo et al., 2009). Starting from this

166 consideration, we decided to use a primer set for vertebrates.

167 Therefore, polymerase chain reaction (PCR) amplifications were performed using 16Smam_1

168 (5'-CGGTTGGGGTGACCTCGGA-3') and 16Smam_2 (5'-GCTGTTATCCCTAGGGTAACT-

169 3') primers, that allow the amplification of a small DNA fragment of about 140 bp of 16S rRNA

170 mitochondrial (mt) gene in all vertebrates (Taylor, 1996; Ficetola et al., 2010), useful when

171 working on highly fragmented and heterogenous materials such as faecal DNA (Valentini,

172 Pompanon \& Taberlet, 2009; Vynne et al., 2012).

173 We assessed the ability of the primer set to bind and amplify the DNA by performing multiple

174 alignments of the primer sequences and 16S mtDNA of the otter's potential prey in the study area

175 (Caricato et al., 2014), downloaded from National Center for Biotechnology Information (NCBI 
176 GenBank) nucleotide database (Table S1). Then, we correlated the number of mismatches

177 between primer and each sequence, as this could affect amplification success, misrepresenting

178 the true diversity (Geisen et al., 2015).

179

180

Amplification of $16 S$ rRNA gene

181 The amplification primers were modified with an Illumina adapter added to 5'ends (Valentini,

182 Pompanon \& Taberlet, 2009; Coissac, Riaz \& Puillandre, 2012).

183 Each tube contained a total of $25 \mu \mathrm{L}$ of PCR mix composed by $50 \mathrm{ng}$ of DNA, Taq polymerase, $1840.8 \mathrm{M}$ Tris- $\mathrm{HCl}, 0.2 \mu \mathrm{M}\left(\mathrm{NH}_{4}\right)_{2} \mathrm{SO}_{4}, 0.2 \% \mathrm{w} / \mathrm{v}$ Tween-20, $2.5 \mathrm{mM} \mathrm{MgCl} 2,0.4 \mathrm{mM}$ dNTP mix 185 and $0.2 \mu \mathrm{M}$ of each primer. For each sample, two PCR replicates were performed. Furthermore, 186 a negative control (sterilized distilled water) was included during this procedure to check the 187 performance of the reactions.

188 The cycles of amplification started with $94^{\circ} \mathrm{C}$ for $5 \mathrm{~min}$ and 35 cycles of $95^{\circ} \mathrm{C}$ for $1 \mathrm{~min}, 55^{\circ} \mathrm{C}$

189 for $1 \mathrm{~min}, 72^{\circ} \mathrm{C}$ for $90 \mathrm{sec}$, and a final extension step at $72^{\circ} \mathrm{C}$ for $5 \mathrm{~min}$.

190

191 Pooling of samples

192 After purification with Illustra GFX PCR DNA and Gel Band Purification Kit (GE Healthcare,

193 Buckinghamshire, UK), PCR replicates for each sample were combined, and DNA in all PCR

194 samples was mixed in equimolar concentrations (Harris et al., 2010) to obtain 5 pools, according

195 to the geographical distribution of the spraints. Each pool was created as a representative of a

196 different type of watercourse, assuming that the content was representative of the prey spectrum

197 of a specific type of river/lake:

198 Pool 1: The Verzarulo stream, tributary located near the origin of the Agri river $(\mathrm{N}=8)$; 
199 Pool 2: main course of the Agri river, located upstream of the Pietra del Pertusillo lake, at the 200 confluence with the Caolo river $(\mathrm{N}=12)$;

201 Pool 3: the Maglie river, flowing into the Pietra del Pertusillo lake $(\mathrm{N}=9)$;

202 Pool 4: the Pietra del Pertusillo lake $(\mathrm{N}=12)$;

203 Pool 5: main course of the Agri river flowing downstream of the Pietra del Pertusillo lake, at the 204 confluence with the Racanello river $(\mathrm{N}=8)$.

205

\section{High Throughput Sequencing and bioinformatic analysis of sequence data}

207 Large-scale sequencing was performed with a 2x150 bp paired-end run using the Illumina MiSeq 208 platform (Illumina, Inc., San Diego, CA, USA), chosen because of lower error rates than other 209 next generation platforms (D’Amore et al., 2016).

210 The Nextera DNA Sample Library Preparation protocol was performed at Genomix4Life Srl

211 (http://www.genomix4life.com/it/). The negative control (sterilized distilled water) and an

212 internal positive control were processed together with our samples in high throughput

213 sequencing. Additionally, a sample containing a known microorganism was included in each

214 sequencing run on the TapeStation (Agilent Technologies, Santa Clara, CA).

215 Analysis of sequencing data, using software (Camacho et al., 2009; Luo et al., 2012; Bokulich et 216 al., 2013; Bolger, Lohse \& Usadel, 2014) implemented in Linux environment, was conducted as

217 previously described in Buglione et al. 2018, with slight modifications according to the

218 molecular markers utilized. In particular, we trimmed and then cropped the reads with low phred

219 quality score $(\mathrm{Q}<30)$ and a minimum length of $35 \mathrm{nt}$. During the blast of the contig sequences

220 against the nucleotide records in NCBI (National Center for Biotechnology Information), we

221 only selected alignments with an E-value $<0.05$, a ratio between the length of the sequence and 
222 the alignment (alignment score) $>80 \%$ and identity $>90 \%$. Furthermore, the blast results were

223 filtered considering a list of otter prey availability to increase the accuracy of automatic

224 taxonomic assignation (Caricato et al., 2014).

225 The software bwa-0.7.12 (Li \& Durbin, 2009), samtools 1.3 (Li et al., 2009) and samstat 1.5.1

226 (Lassmann, Hayashizaki \& Daub, 2011) were used to perform mapping for quantitative analysis.

227 The reference contigs, assigned to the corresponding taxa during the blast, were used for the 228 alignment of reads. Both chimeric alignments (supplementary alignments) and secondary

229 alignments were detected and removed with samtools 1.3 (see SAM Alignment/Map Format

230 Specification at https://github.com/samtools/hts-specs). Finally, in the calculation of the number

231 of reads for a taxonomic assignment, we considered all sequences with count $>1$ (Mollot et al., 232 2014).

233

234 Statistical analysis

235 For each pool, we calculated the percent of occurrence (PO\%) of each taxon as the number of the 236 DNA reads assigned to a taxon divided by total number of DNA reads of all identified taxa in a 237 pool. Furthermore, we provided the relative read abundance (RRA) of the taxa in the otter's diet, 238 defining it as the average of the percent of occurrence of a specific taxon across all samples. This 239 result was shown in a box plot reporting minimum, maximum, median, quartiles, upper and 240 lower whiskers, and outliers.

241 Alpha diversity descriptors (richness and the Shannon Index) were elaborated for the five pools

242 using Past v. 3.2. software (Hammer et al., 2001) and Pearson's chi-square test was applied to

243 data sets to assess how likely any observed differences between pools were due to chance.

244 Finally, to examine the variation of preys between the pools and highlight the taxa most 
245 represented in the five different sampling sites, we performed a Correspondence Analysis (CA)

246 implemented in R v. 3.6.1 (Borcard, Gillet \& Legendre, 2011).

247

248 Results

249 Considering all the collected samples, DNA was successfully extracted in $96.07 \%$ of cases (49

250 samples) with DNA concentration ranging between [20 - $885 \mathrm{ng} / \mu \mathrm{L}]$ and with both $\lambda_{260 / 280}$ and $251 \quad \lambda_{260 / 230}>1.50$.

252 The primers bound the DNA of all the considered potential prey in the study area (fish and

253 amphibians) with a mismatch between primer and prey sequence not higher than 4 (forward) or 1

254 (reverse) nucleotide bases (Fig. S1).

255 A total of 20,957,120 short raw reads ( $150 \mathrm{bp}$ ) was obtained from Illumina MiSeq sequencing of 256 the DNA extracted and amplified from the 49 spraints. During library preparation, no amplicons

257 were detected for the negative control and, similarly, no reads derived from its sequencing on the 258 Illumina platform, revealing no out contaminations.

259 After trimming, 6,717,838 filtered reads were retained for subsequent analyses. After assembly,

260123 '500 sequences were used for the blasting against NCBI database, of which $96.54 \%$ found a

261 correspondence with deposited nucleotide sequences. Finally, we obtained 113,296 sequences on

262 which we performed quantitative analysis, calculating the number of reads for each taxonomic

263 assignment. Bioinformatics processing of the sequencing data was performed separately for the 5

264 pools (see details in Table 1).

265 The automatic taxonomic assignment of the sequences revealed the presence of DNA ascribable

266 to mammals (otters, wild boars, hares, cows, goats, rats and mice) and birds, although

267 represented by few sequences. 
268 These findings suggest an interaction with these species or with parts of them (such as

269 excrements, carcasses or fur), although this does not necessarily imply predation events

270 (O'Sullivan et al., 1992). For this reason, these sequences, as well as otter DNA sequences, were

271 not considered in the final processing of the diet data, retrieving only sequences assigned to

272 Pisces and Amphibia.

273 The results from molecular analyses of the otter's diet showed that the total number of reads was

274 dominated by DNA from fishes (99.14\%) while amphibians represented $0.85 \%$, mirroring an

275 estimate of the relative proportion of these items ingested by the otter (Deagle, Kirkwood \&

276 Jarman, 2009; Pompanon et al., 2012), and resulted in 6 families (Fig. 2 and Table 2).

277 Cyprinidae ( $97.77 \%$ of total reads) was the dominant family, consisting of 16 different species.

278 The Italian bleak (Alburnus albidus), together with the Italian barbel (Barbus plebejus),

279 accounted for $77.24 \%$ of the total reads of DNA sequences for all samples, and $79 \%$ of all

280 Cyprinidae species (Fig. 2A and Table 2). The remaining families were each represented by one

281 species: Percidae (the common perch Perca fluviatilis, 1.31\%), Ranidae (the Italian stream frog

282 Rana italica, 0.85\%), Gobidae (the Arno goby Padogobius nigricans, 0.026\%), Salmonidae (the

283 brown trout Salmo trutta, $0.025 \%$ ) and Bufonidae (the common toad Bufo bufo, $<0.01 \%$ ) (Fig.

284 2A and Table 2). The relative read abundance of the different species in the food of the otter (Fig.

285 2B and Table 2) highlights how the Italian barbel, the Italian bleak, the Italian chub (Squalius

286 squalus), and the South European Roach (Sarmarutilus rubilio) are the most represented

287 indigenous species, even if we cannot reliably conclude that these are the real relative

288 relationships among the preys. The common carp (Cyprinus carpio), the perch, the trout and the

289 frog show appreciable levels of relative read abundance, albeit with a large variance due to their

290 spatial segregation. In particular, carps and perches are present in high percentage in the diet of 
291 otters from the Pietra del Pertusillo lake while frogs are included in the diet of otters sampled on

292 the river courses upstream of the lake.

293 The diet characterization of the spraints in pool 1 revealed 12 taxa with a resolution at species

294 level in $85.92 \%$ of cases, at genus level in $1.93 \%$ of cases and at family level in $12.13 \%$ of cases.

295 Cyprinidae (99.75\%) was the most abundant family ingested by the otters, followed by Ranidae

296 (Rana italica, 0.24\%). Considering Cyprinidae, the Italian bleak and the Italian barbel seem to be

297 the most abundant fish items, with a percent of occurrence $\geq 30 \%$. We also revealed sequences

298 assigned to the Tyrrhenian rudd (Scardinius scafandra) and the asp (Aspius aspius), although at

299 very low percentages $(<0.002 \%)$ (Table 2$)$.

300 Analysis of DNA extracted from spraints included in pool 2 showed 11 taxa with identification

301 at species level for $19.59 \%$ of the sequences, at genus level for $25.67 \%$ and at family level in

$30254.73 \%$ of cases. For pool 2, Cyprinidae (95.83\%) was again found to be the most occurring

303 family in the diet of otters sampled on the Agri-Caolo watercourse, followed by Ranidae

$304(2.75 \%)$, only represented by the Italian frog. The Crucian carp (Carassius sp.) was the most

305 frequently occurring item (25.79\%) among Cyprinidae, followed by the Italian barbel (8.77\%),

306 the Italian chub (2.86\%), the common carp (2.07\%) and the Italian bleak (1.65\%). All remaining

307 cyprinid species found had a percent of occurrence $<1 \%$. Besides Cyprinidae, Gobidae $(1.15 \%)$

308 and Salmonidae (0.29\%) families were found. In particular, the brown trout represented the only

309 species revealed for Salmonidae (Table 2).

310 Spraints in pool 3 showed a diet composed by 13 taxa, assigned at species level, genus level and 311 at family level in $35.52 \%, 62.06 \%$ and $2.38 \%$ of cases, respectively. 
312 Cyprinidae (73.95\%) was the most frequently occurring family, of which Carassius sp. (83.91\%)

313 exhibited the highest percent of occurrence. Cyprinidae was followed by Ranidae (25.14\%),

314 Salmonidae (0.80\%), Percidae (0.09\%) and Bufonidae (0.004\%) (Table 2).

315 Food determination for spraints in pool 4 showed a diet composed by 9 fish taxa, with a

316 percentage of sequence assignment at species level of $60.12 \%$, at genus level of $39.77 \%$ and at

317 family level of $0.12 \%$. Diet was dominated by Cyprinidae (55.30\%) and Percidae (44.72\%).

318 Carassius sp. was the most frequent taxa in Cyprinidae (71.92\%), followed by the Italian barbel

319 (14.94\%). The remaining sequences had a percent of occurrence $<10 \%$ (Table 2 ).

320 At last, diet analysis for spraints in pool 5 showed the highest number of taxa $(\mathrm{S}=16$; Fig. 3$)$ but

321 they are included in only two fish families (Cyprinidae and Percidae), with $97.57 \%$ of sequences

322 assigned to species level. For these samples as well, Cyprinidae (99.77\%) was the dominant

323 family. Considering the latter, the Italian barbel showed the highest percent of occurrence

324 (45.11\%), followed by the Italian chub (30.71\%) and the South European Roach (18.55\%). The

325 other cyprinid species were found with a percent of occurrence $<2 \%$. We revealed, although at

326 low percentages $(<0.6 \%)$, some fish species typical of Caucasus areas (between the Black Sea

327 and the Caspian Sea), like the white-eye bream (Ballerus sapa, 0.24\%) and the white bream

328 (Blicca bjoerkna, 0.002\%) (Table 2).

329 The diet of the otter changes according to the structure of the watercourse (Fig. 3). The greatest

330 diet diversity (meaning richness in fish and amphibian families preyed) characterizes the otters

331 from the main course of the Agri river, downstream of the Pietra del Pertusillo lake (pool 5). In

332 the lake, the number of species in the spraints mainly belongs to Cyprinidae and Percidae,

333 showing a drastic depletion in number of species detected in the scats (pool 4). On the rivers and

334 tributaries, upstream of the lake (pools 1,2 and 3) spraints are characterized by the presence of 
335 items from the Ranidae family, although in different percentages, and the diet richness, in terms

336 of items ingested by otters, is comparable. The highest value of Shannon-Weaver index was

337 recorded on the main river Agri (pool 2) (Fig. 3A).

338 Correspondence Analysis ordered the diets taken from the pools based on the information

339 deriving from the variables (items). Total variance generated the dimensions DM1, DM2 and

340 DM3 that accounted for $37.07 \%, 26.34 \%$ and $20.75 \%$, respectively. Biplot highlights the

341 contribution of the most significant variables in the relative arrangement among the pools (Fig.

342 3B). The diet of pool 1 is affected mainly by the presence of the Italian bleak. The Italian barbel,

343 together with the contribution of the Italian chub and the South European Roach, characterize the

344 composition of pool 5, downstream of the lake. The diet of the otters on the Pietra del Pertusillo

345 lake (pool 4) is influenced mainly by the common perch, whereas Carassius sp. affects the diet

346 of the otters on the Maglie river (pool 3). Unclassified cyprinids weigh heavily in the diet of

347 pool 2 (Fig. 3B).

348

349 Discussion

350 The Eurasian otter is a top predator in freshwater habitats, can therefore play an important role in

351 the functioning and structuring of the ecosystem (Ayres \& García, 2011; Day, Westover \&

352 McMillan, 2015; Berger et al., 2001). The analysis of its food habits could improve the

353 knowledge of both the ecological requirements of this species and of the species composition of

354 communities from the river system.

355 Generally, all the fish species inhabiting the Agri river and its tributaries reproduce in the period

356 from May until the summer, with a production of juvenile fish in summer and autumn. 
357 This is important because it could influence the rate at which a certain taxon is consumed. Our

358 sample collection covers this period so that the otters we surveyed had the opportunity to prey on

359 individuals of different age, of the species identified.

360 The ontogenesis of fish species found in the otter's diet could be very variable, with a potentially

361 wide spectrum of body sizes. However, the size of the river, the salinity and the temperature

362 evens communities and fish body sizes among adults of various species. Our analyses have, most

363 probably, been conducted on otters of different genders and at different life stages. Indeed,

364 working with scats we knew that no gender or age-related restrictions exist in faecal marking

365 activities. Both sexes used the marking points and the high number of droppings from juvenile

366 otters demonstrates that the use of marking points is not restricted to adults (Kalz, Jewgenow \&

367 Fickel, 2006).

368 DNA metabarcoding coupled with HTS represented a good approach for analyzing the diet of

369 otters from Southern Italy using DNA extracted from non-invasive samples, in terms of

370 accuracy, cost, time, and effort (Deagle, Kirkwood \& Jarman, 2009; Soininen et al., 2009;

371 Pompanon et al., 2012; Berry et al., 2015; Kumari et al., 2019; Martinez-Abrain et al., 2020).

372 However, in the interpretation of data, we proceeded with caution. In fact, the use of reads count

373 as a direct measure of ingested biomass remains a highly debated issue (Deagle et al., 2019;

374 Kumari et al., 2019) and some considerations should be taken into account before doing so.

375 Ideally, the number of sequences assigned to a taxon would mirror the biomass in faecal

376 material. However, several factors, acting from collection to sequencing, could alter this

377 correspondence (Deagle et al., 2009; Vynne et al., 2012; Valentini et al., 2009; Pompanon et al.,

378 2012; Deiner et al., 2017; Gloor et al., 2017; Porter \& Hajibabaei, 2018). Indeed, rather than the

379 absolute interpretation of data, reads count represents a comparative estimation among items 
380 revealed by sequencing analysis (Pompanon et al., 2012; Deagle et al., 2019). In our case,

381 taxonomic assignment allowed us to discriminate at species level resolution. In some cases, the

382 incompleteness of the reference database or the quality of the extracted DNA only allowed

383 assignment at the family or genus level. For example, after automatic taxonomic assignment and

384 filtering, we decided to assign $6.08 \%$ of the total sequences to the genus Carassius, without

385 attempting a specific diagnosis. Indeed, the characterization of the fish fauna in the Basilicata

386 rivers (Caricato et al., 2014) revealed the presence of Carassius carassius and Carassius

387 auratus.

388 Our findings showed that the diet of the otter is dominated by cyprinids, in agreement with their

389 abundance in the Southern Italian rivers (Prigioni et al., 2006a; Bianco, 2014).

390 Although it is necessary to carefully evaluate the comparisons between the percentages of

391 presence of each item sequenced, an autochthonous species was the predominantly consumed

392 species in the case of Alburnus albidus (45.27\%) and Barbus plebejus (31.95\%).

393 The allochthonous Carassius sp. and Perca fluviatilis follow in importance as components of

394 otter diet, and they show a wide distribution in pools of our study area. Also, Salmo trutta could

395 refer to the introduced Atlantic lineage, given its appeal to sport fishermen. Moreover, our

396 sequences do not blast against the indigenous Mediterranean lineage deposited in the NCBI

397 database. However, due to taxonomic disagreement on these species in the scientific community,

398 we need further and in-depth analysis to disentangle this doubt.

399 We only found Salmo trutta in samples collected at the confluence between the Caolo and the

400 Agri river (pool 2) and in samples from the Maglie river (pool 3), together with cyprinids. The

401 latter finding underlines the ability of otters to reveal species that did not emerge during the 
402 previous electrofishing survey, which reported trout as the only fish species in the Caolo river

403 and in the upper part of the Maglie river (Prigioni et al., 2006a).

404 Many results suggest that the otter is a generalist predator, and its diet seems to vary according to 405 prey availability (Prigioni et al., 2006a). In the case of Squalius squalis, reported only in the

406 lowest part of the Agri river (named Leuciscus cephalus in Prigioni et al., 2006a), our data show

407 its presence in the spraints from all pools in a percentage ranging from $0.13 \%$, in the upper part 408 of Agri to $30.64 \%$ in the lower part.

409 Rutilius rubilio was indicated as one of the preferred food items for otters in Southern Italy

410 (Prigioni, 1997) and a gradual decline in its frequency of occurrence was registered from 1989-

$4111990(50 \%)$ to $2001-2002(15 \%)$, ascribable to an increase in centrarchid consumption

412 (Balestrieri et al., 2006; Prigioni et al., 2009). Our diet analysis revealed Salmorutilius rubilio

413 [synonymous] in all sites, mainly downstream of the dam (18.51\%) where it is probably the most 414 abundant species.

415 In some cases, the molecular method revealed the presence of species that were not previously

416 recorded in the study areas, for example the allochthonous species Aspius aspius, Ballerus sapa,

417 Blicca bjoerkna, Luciobarbus sp., Padogobius nigricans. Moreover, Aspius aspius, introduced in

418 Italy in the twentieth century, is a novelty for the Agri river, and it has been reported only up to

419 central Italy in some artificial basins in the province of Rieti (Bianco, 2014).

420 These findings probably depend on the higher sensitivity of molecular methods in both food

421 detection and identification, revealing also non-solid items or preys ingested at low percentages

422 (Soininen et al., 2009; Ando et al., 2013; Zarzoso-Lacoste et al., 2016).

423 Amphibians represented $0.85 \%$ of the total items ingested by the otters and were included in the

424 diet of pools from the upper part of the river. This finding could depend on the ecological 
425 requirements of the autochthonous Rana italica, endemic of the Italian peninsula, living in the

426 source of mountain streams, linked to clear and cool water. Smiroldo et al. 2009 reported that the

427 frequency of consumption of amphibians in the diet of the otter increased with the altitude of

428 sampling stations (Remonti et al., 2008; Smiroldo et al., 2009).

429 In some cases, molecular analyses allowed to resolve uncertainties emerging from the

430 morphological approach. For example, morphological analyses revealed the presence of Rana sp.

431 and Bufo sp. (Prigioni et al., 2006a; Smiroldo et al., 2009) while molecular analyses refined this

432 assignment to Rana italica and Bufo bufo, respectively. The diversity of fish in the otter diet

433 shows an impoverishment in the pools sampled upstream of the dam. Also, from the multivariate

434 analysis (biplot) pool 5 seems to be characterized by a greater number of variables. This trend

435 could be consistent with the impact of these anthropogenic structures on fish diversity, probably

436 hindering the movements of some species along the river axis. In some cases, the impacts of the

437 dam were compensated by building channels for lifts that bypass the barrier (Harris et al., 2017;

438 Voicu et al., 2020).

439

440 Conclusion

441 Our study effectively highlights the variability in the diet of closely related otter populations

442 confirming some evidence put forth by other authors, and allowing the depiction of a more

443 precise trophic niche for this species. Indigenous species of cyprinids represent the main trophic

444 source, although alien species constitute a non-negligible percentage of their diet.

445 In fact, out of twelve alien species only three (Carassius sp., Ciprinus carpio and Perca

446 fluviatilis) stand out with an appreciable presence, and this occurs primarily close to lake

447 environments (Lanszki et al., 2007). The recent review on the importance of non-native fish in 
448 the diet suggests their slight increase with time, probably as a consequence of alterations in the

449 fish assemblages (Balestrieri et al., 2017). Could this also be the case of Pertusillo lake and Agri

450 system in general? Probably yes, if we consider that the introduction of alien species has been

451 growing over time, as highlighted also by the presence of Aspius aspius, a species that has only

452 recently found much appreciation among anglers. This data seems to be alarming, if we consider

453 that, in the near future the fresh waters of Basilicata will be populated by allochthonous species

454 up to $78 \%$ (Caricato et al., 2014).

455 Our findings could help define strategies useful for the conservation of the otter in Southern

456 Italy, suggesting management actions directed at fishing regulations affecting food availability.

457 In order to avoid alterations of otter food availability and native fish communities, some actions

458 need to be taken. For example, the interruption of all kinds of introduction in the National Park

459 and adjoining areas, especially using stocks of unknow origin; as well as controls on the health

460 and taxonomic status of stocks using genetic approaches.

461

462

463 Acknowledgments

464 We thanks to Ente Parco Nazionale dell'Appennino Lucano, Val d'Agri-Lagonegrese for supply

465 some samples. In particular, we are grateful to Remo Bartolomei, Donata Coppola, and Luciano

466 Ferraro for their help during sample collection. We are grateful to Gianluca Zuffi for valuable

467 suggestions provided about the ichthyology of Italy.

468

469 References 
470 Ando H, Setsuko S, Horikoshi K, Suzuki H, Umehara S, Inoue-Murayama M, Isagi Y. 2013.

471 Diet analysis by next-generation sequencing indicates the frequent consumption of introduced

472 plants by the critically endangered red-headed wood pigeon (Columba janthina nitens) in

473 oceanic island habitats. Ecology and Evolution 3:4057-4069. DOI:https:

474 //doi.org/10.1002/ece3.773.

475

476

Arcà G, Cassola F. 1986. La lontra in Calabria. La Lontra in Italia. Serie Atti e Studi 5: 118-121.

477

478

Ayres C, García P. 2011. Features of the predation of the Eurasian otter upon toads in north-

479

western Spain. Mammalian biology 76:90-92. DOI:

480

https://doi.org/10.1016/j.mambio.2010.03.002.

481

482 Balestrieri A, Prigioni C, Remonti L, Sgrosso S, Priore G. 2006. Feeding ecology of Leuciscus

483 cephalus and Rutilus rubilio in southern Italy. Italian Journal of Zoology, 73:129-135. DOI:

484 https://doi.org/10.1080/11250000600679561.

485

486

Balestrieri A, Remonti L, Smiroldo G, Prigioni C, Reggiani G. 2008. Surveying otter Lutra lutra

487 distribution at the southern limit of its Italian range. Hystrix, the Italian Journal of Mammalogy

488

19. DOI: $10.4404 /$ hystrix-19.2-4426.

489 
490 Balestrieri A, Remonti L, Prigioni C. 2009. Exploitation of food resources by the Eurasian 491 badger (Meles meles) at the altitudinal limit of its Alpine range (NW Italy). Zoological science 492 26: 821-827. DOI: https://doi.org/10.2108/zsj.26.821.

493

494 Berger J, Stacey PB, Bellis L, Johnson MP. 2001. A mammalian predator-prey imbalance:

495 Grizzly bear and wolf extinction affect avian neotropical migrants. Ecological Applications 11:

496 947-960. DOI: https://doi.org/10.1890/1051-0761(2001)011[0947:AMPPIG]2.0.CO;2.

497

498

Berry O, Bulman C, Bunce M, Coghlan M, Murray DC, Ward RD. 2015. Comparison of

499

morphological and DNA metabarcoding analyses of diets in exploited marine fishes. Marine

500 Ecology Progress Series 540:167-181. DOI: 10.3354/meps11524.

501

502 Bianco PG. 2014. An update on the status of native and exotic freshwater fishes of Italy. Journal 503 of Applied Ichthyology 30: 62-77. DOI: https://doi.org/10.1111/jai.12291.

504

505 Borcard D., Gillet F., Legendre P. 2011. Numerical Ecology with R. New York: Springer.

506

507 Boitani L, Lovari S, Vigna Taglianti A. 2003. Fauna d'Italia, Mammalia III: Carnivora 508 Artiodactyla Calderini. 
510 Bokulich NA, Subramanian S, Faith JJ, Gevers D, Gordon JI, Knight R, Millis AD, Caporaso

511 JG. 2013. Quality-filtering vastly improves diversity estimates from Illumina amplicon

512 sequencing. Nature methods 10: 57-59. DOI: 10.1038/nmeth.2276.

513

514 Bolger AM, Lohse M, Usadel B. 2014. Trimmomatic: a flexible trimmer for Illumina sequence 515 data. Bioinformatics 30: 2114-2120. DOI:10.1093/bioinformatics/btu170.

516

517 Buglione M, Maselli V, Rippa D, de Filippo G, Trapanese M, Fulgione D. 2018. A pilot study on

518 the application of DNA metabarcoding for non-invasive diet analysis in the Italian hare.

519 Mammalian Biology 88: 31-42. DOI: https://doi.org/10.1016/j.mambio.2017.10.010.

520

521 Buglione M, Petrelli S, Notomista T, de Filippo G, Gregorio R, Fulgione D. 2020. Who is who?

522 High Resolution Melting analysis to discern between hare species using non-invasive sampling.

523 Conservation Genetics Resources. DOI: https://doi.org/10.1007/s12686-020-01153-9.

524

525 Camacho C, Coulouris G, Avagyan V, Ma N, Papadopoulos J, Bealer K, Madden TL. 2009.

526 BLAST+: architecture and applications. BMC bioinformatics 10: 421. DOI: 10.1186/1471-2105-

$527 \quad 10-421$.

528

529 Caricato G, Canitano M, Montemurro M. 2014. Alien vs native species into freshwaters of 530 Basilicata. Quaderni ETP 35:11-20. 
532 Carss D. 1995. Foraging behaviour and feeding ecology of the otter Lutra lutra: a selective

533 review. Hystrix, the Italian Journal of Mammalogy 7. DOI: https://doi.org/10.4404/hystrix-7.1-25344069.

535

536 Cassola F. 1986 The Otter in Italy. Status, Distribution and Conservation of an Endangered

537 Species. WWF Italia, Serie Atti e Studi 5.

538

539 Clavero M, Prenda J, Delibes M. 2003. Trophic diversity of the otter (Lutra lutra L.) in

540 temperate and Mediterranean freshwater habitats. Journal of Biogeography 30: 761-769.

541 doi:10.1046/j.1365-2699.2003.00865.x.

542

543 Coissac E, Riaz T, Puillandre N. 2012. Bioinformatic challenges for DNA metabarcoding of

544 plants and animals. Molecular Ecology 21:1834-1847. DOI: 10.1111/j.1365-

545 294X.2012.05550.x.

546

547 Conroy JW, Chanin PR. 2000. The status of the Eurasian otter (Lutra lutra) in Europe. A

548 Review. Journal of the International Otter Survival Fund 1:7-28.

550 Conroy JW, Chanin PR. 2002. The status of the Eurasian otter (Lutra lutra). IUCN Otter

551 Specialist Group Bulletin A, 19:24-48. 
552

553 Dallas JF, Carss DN, Marshall F, Koepfli KP, Kruuk H, Bacon PJ, Piertney SB. 2000. Sex

554 identification of the Eurasian otter Lutra lutra by PCR typing of spraints. Conservation

555 Genetics 1: 181-183. DOI: 10.1023/A:1026551510861.

556

557 Day CC, Westover MD, McMillan BR. 2015. Seasonal diet of the northern river otter (Lontra

558 canadensis): what drives prey selection? Canadian Journal of Zoology 93: 197-205. DOI:

559 https://doi.org/10.1139/cjz-2014-0218.

560

561 D’Amore R, Ijaz UZ, Schirmer M, Kenny JG, Gregory R, Darby AC, Shakya M, Podar M,

562 Quince C, Hall N. 2016. A comprehensive benchmarking study of protocols and sequencing

563 platforms for 16S rRNA community profiling. BMC genomics 17: 55. DOI:

564 https://doi.org/10.1186/s12864-015-2194-9.

565

566

De Castro G, Loy A. 2007. Un nuovo censimento della lontra (Lutra lutra, Carnivora,

567 Mammalia) nel fiume Sangro (Abruzzo): inizia la ricolonizzazione dell'Italia centrale? 68

568 Convegno Unione Zoologica Italiana, Lecce.

569

570 Deagle BE, Kirkwood R, Jarman SN. 2009. Analysis of Australian fur seal diet by

571 pyrosequencing prey DNA in faeces. Molecular ecology 18: 2022-2038. DOI: 10.1111/j.1365-

572 294X.2009.04158.x.

Peer] reviewing PDF | (2020:03:47089:2:1:NEW 25 Jun 2020) 
574 Deagle BE, Thomas AC, McInnes JC, Clarke LJ, Vesterinen EJ, Clare EL, Kartzinel TR, Eveson

575 JP. 2019. Counting with DNA in metabarcoding studies: How should we convert sequence reads

576 to dietary data? Molecular ecology 28:391- 406. DOI: https://doi.org/10.1111/mec.14734.

577

578 Deiner K, Renshaw MA, Li Y, Olds BP, Lodge DM, Pfrender ME. 2017. Long-range PCR allows

579 sequencing of mitochondrial genomes from environmental DNA. Methods in Ecology and 580 Evolution 8:1888-1898. DOI: https://doi.org/10.1111/2041-210X.12836.

581

582 Ficetola GF, Coissac E, Zundel S, Riaz T, Shehzad W, Bessière J, Taberlet P, Pompanon F.

583 2010. An in silico approach for the evaluation of DNA barcodes. BMC genomics 11:434. DOI:

584 https://doi.org/10.1186/1471-2164-11-434.

585

586 Fusillo R, Marcelli M, Boitani L. 2003. Progetto di ricerca sulla lontra nel Parco Nazionale del

587 Cilento e Vallo di Diano. Relazione conclusiva. Parco Nazionale del Cilento e Vallo di Diano.

588 Università di Roma, La Sapienza.

589

590 Geisen S, Laros I, Vizcaíno A, Bonkowski M, De Groot GA. 2015. Not all are free-living:

591 high-throughput DNA metabarcoding reveals a diverse community of protists parasitizing soil

592 metazoa. Molecular Ecology 24:4556-4569. DOI: 10.1111/mec.13238. 
594 Giovacchini S, Marrese, M, Loy A. 2018. Good News from the South: Filling the Gap between

595 Two Otter Populations in Italy. IUCN Otter Spec. Group Bull 35: 212-221.

596

597 Gloor GB, Macklaim JM, Pawlowsky-Glahn V, Egozcue JJ. 2017. Microbiome datasets are 598 compositional: and this is not optional. Frontiers in microbiology 8:2224. DOI: 599 https://doi.org/10.3389/fmicb.2017.02224.

600

601 Goossens B, Chikhi L, Utami SS, de Ruiter J, Bruford MW. 2000. A multi-sample, multi602 extracts approach for microsatellite analysis of faecal samples in an arboreal ape. Conservation 603 Genetics 1: 157 - 162. DOI: https://doi.org/10.1023/A:1026535006318.

604

605 Hammer Ø, Harper DA, Ryan PD. 2001. PAST: Paleontological statistics software package for 606 education and data analysis. Palaeontologia electronica 4:9.

607

608 Harris JK, Sahl JW, Castoe TA, Wagner BD, Pollock DD, Spear JR. 2010. Comparison of 609 normalization methods for construction of large, multiplex amplicon pools for next-generation 610 sequencing. Applied environmental Microbiology 76: 3863-3868. DOI:10.1128/AEM.02585-09.

611

612 Harris JH, Kingsford RT, Peirson W, Baumgartner L 2017. Mitigating the effects of barriers to 613 freshwater fish migrations: The Australian experience. Marine and Freshwater Research 68(4): 614 614-628. https://doi.org/10.1071/MF15284 
615

616 Hilton-Taylor C. 2000. IUCN red list of threatened species. Available at IUCN

617 http://www.redlist.org.

618

619 Jansman HAH, Chanin PRF, Dallas JF. 2001. Monitoring otter populations by DNA typing of 620 spraints. IUCN Otter Specialist Bulletin 18:11-18.

621

622 Kalz B, Jewgenow K, Fickel J 2006. Structure of an otter (Lutra lutra) population in Germany 623 results of DNA and hormone analyses from faecal samples. Mammalian Biology 71: 321-335.

624 Doi:10.1016/j.mambio.2006.02.010

625

626 Kumari P, Dong K, Eo KY, Lee WS, Kimura J, Yamamoto N. 2019. DNA metabarcoding-based

627 diet survey for the Eurasian otter (Lutra lutra): Development of a Eurasian otter-specific blocking 628 oligonucleotide for $12 \mathrm{~S}$ rRNA gene sequencing for vertebrates. PloS one 14. DOI: 62910.1371 journal.pone.0226253.

630

631 Lanszki J, Pallos ZS, Nagy D, Yoxon G. 2007. Diet and fish choice of Eurasian otters (Lutra lutra 632 L.) in fish wintering ponds in Hungary. Aquaculture International 15:393-402. DOI: $63310.1007 / \mathrm{s} 10499-007-9103-4$.

634 
635 Lassmann T, Hayashizaki Y, Daub CO. 2011. SAMStat: monitoring biases in next generation 636 sequencing data. Bioinformatics 27:130-131. DOI:10.1093/bioinformatics/btq614.

637

638 Li H, Durbin R. 2009. Fast and accurate short read alignment with Burrows-Wheeler 639 transform. Bioinformatics 25:1754-1760. DOI: 10.1093/bioinformatics/btp324.

640

641 Li H, Handsaker B, Wysoker A, Fennell T, Ruan J, Homer N, Marth G, Abecasis G, Durbin R. 642 2009. The sequence alignment/map format and SAMtools. Bioinformatics 25:2078-2079. DOI: 643 https://doi.org/10.1093/bioinformatics/btp352.

644

645 Loy A, Carranza ML, Cianfrani C, D'Alessandro E, Bonesi L, Di Marzio P, Minotti M, Reggiani 646 G. 2009. Otter Lutra lutra population expansion: assessing habitat suitability and connectivity in 647 southern Italy. Folia Zoologica-Praha 58: 309-326.

648

649 Loy A, Boitani L, Bonesi L, Canu A, Di Croce A, Fiorentino PL, Genovesi P, Mattei L, 650 Panzacchi M, Prigioni C, Randi E, Reggiani G. 2010. The Italian action plan for the endangered 651 Eurasian otter Lutra lutra. Hystrix, the Italian Journal of Mammalogy 21. DOI:

652 https://doi.org/10.4404/hystrix-21.1-4483.

653

654 Luo R, Liu B, Xie Y, Li Z, Huang W, Yuan J, He G, Chen Y, Pan Q, Liu Y, Tang J, Wu G, 655 Zhang H, Shi Y, Yong Liu, Yu C, Wang B, Lu Y, Han C, Cheung DW, Yiu SM, Peng S, 
656 Xiaoqian Z, Liu G, Liao X, Li Y, Yang H, Wang J, Lam TW, Wang J. 2012. SOAPdenovo2: an

657 empirically improved memory-efficient short-read de novo assembler. Gigascience 1:2047-

658 217X. DOI: https://doi.org/10.1186/2047-217X-1-18.

659

660 Macdonald SM, Mason CF. 1983. The otter Lutra lutra in Southern Italy. Biological

661 Conservation 25:95-101 https://doi.org/10.1016/0006-3207(83)90054-X.

662

663 MacDonald SM, Mason CF. 1994. Status and conservation needs of the otter (Lutra lutra) in the 664 western Palaearctic. Strasbourg: Council of Europe.

665

666 Martínez-Abraín A, Marí-Mena N, Vizcaíno A, Vierna J, Veloy C, Amboage M, Guitián-

667 Caamaño A, Key C, Vila M. 2020. Determinants of Eurasian otter (Lutra lutra) diet in a

668 seasonally changing reservoir. Hydrobiologia 847:1803-1816. DOI: 10.1007/s10750-020-04208$669 \mathrm{y}$.

670

671 Mason C. 1995. Habitat quality, water quality and otter distribution. Hystrix-the Italian Journal 672 of Mammalogy 7:1-2. DOI: https://doi.org/10.4404/hystrix-7.1-2-4070.

673

674 Mason CF, Macdonald SM. 1986 Otters: Ecology and Conservation. Cambridge: Cambridge 675 University Press.

676 
677 Mason CF, Macdonald SM. 1994. PCBs and organochlorine pesticide residues in otters (Lutra

678 lutra) and in otter spraints from SW England and their likely impact on populations. Science of

679 the Total Environment 144:305-312.

680

681 Mason, CF Wren CD. 2001. Carnivora. In: Shore RF, Rattner BA, ed. Ecotoxicology of wild 682 mammals. Chichester: John Wiley and Sons, 315-370.

683

684 Menge BA, Sutherland JP. 1976. Species diversity gradients: synthesis of the roles of predation, 685 competition, and temporal heterogeneity. The American Naturalist 110:351-369.

686

687 Mollot, G. Duyck PF, Lefeuvre P, Lescourret F, Martin JF, Piry S, Canard E, Tixier P. 2014.

688 Cover cropping alters the diet of arthropods in a banana plantation: a metabarcoding

689 approach. PloS one 9. DOI:10.1371/journal.pone.0093740.

690

691 Murk AJ, Leonards PE, van Hattum B, Luit R, van der Weiden ME, Smit M. 1998. Application 692 of biomarkers for exposure and effect of polyhalogenated aromatic hydrocarbons in naturally 693 exposed European otters (Lutra lutra). Environmental Toxicology and Pharmacology 6:91-102. 694 DOI: 10.1016/s1382-6689(98)00026-X.

695

696 O'Sullivan WM, Sleeman DP, Murphy DM. 1992. Otters Lutra lutra feeding on carrion. The 697 Irish Naturalists' Journal 24:140-143. 
698

699 Panzacchi M, Genovesi P, Loy A. 2010. Piano d'Azione Nazionale per la Conservazione della

700 Lontra (Lutra lutra). Ministero dell'Ambiente e della Tutela del Territorio e del Mare-Istituto

701 Superiore per la Protezione e la Ricerca Ambientale.

702

703 Pimm SL. 1980. Food web design and the effect of species deletion. Oikos 139-149. DOI:

$704 \quad 10.2307 / 3544422$

705

706 Pompanon F, Deagle BE, Symondson WO, Brown DS, Jarman SN, Taberlet P. 2012. Who is

707 eating what: diet assessment using next generation sequencing. Molecular ecology 2, 1931-1950.

708 DOI: https://doi.org/10.1111/j.1365-294X.2011.05403.x.

709

710 Porter TM, Hajibabaei M. 2018. Scaling up: A guide to high-throughput genomic approaches for

711 biodiversity analysis. Molecular ecology 27:313-338. DOI:https://doi.org/10.1111/mec.14478.

712

713 Prigioni C. 1997. La lontra: una vita silenziosa negli ambienti acquatici. Edagricole.

714

715 Prigioni C, Remonti L, Balestrieri A, Sgrosso S, Priore G, Misin C, Viapiana M, Spada S,

716 Anania R. 2005. Distribution and sprainting activity of the otter (Lutra lutra) in the Pollino

717 National Park (Southern Italy). Ethology Ecology \& Evolution 17: 171-180.

718 DOI:https://doi.org/10.1080/08927014.2005.9522606. 
720 Prigioni C, Balestrieri A, Remonti L, Gargaro A, Priore G. 2006a. Diet of the Eurasian otter

721 (Lutra lutra) in relation to freshwater habitats and alien fish species in southern Italy. Ethology

722 Ecology \& Evolution 18:307-320. DOI:https://doi.org/10.1080/08927014.2006.9522698.

723

724 Prigioni C, Balestrieri A, Remonti L, Sgrosso S, Priore G. 2006b. How many otters are there in

725 Italy? Hystrix, The Italian Journal of Mammalogy 17: 29-3.6 DOI:

726 https://doi.org/10.4404/hystrix-17.1-4362.

727

728 Prigioni C, Balestrieri A, Remonti L. 2007. Decline and recovery in otter Lutra lutra populations 729 in Italy. Mammal Review 37: 71-79. DOI: 10.1111/j.1365-2907.2007.00105.x

730

731 Prigioni C, Smiroldo G, Remonti L, Balestrieri A. 2009. Distribution and diet of reintroduced

732 otters (Lutra lutra) on the river Ticino (northern Italy). Hystrix-the Italian Journal of

733 Mammalogy 20. DOI: https://doi.org/10.4404/hystrix-20.1-4432.

734

735 Randi E, Davoli F, Pierpaoli M, Pertoldi C, Madsen AB, Loeschcke V. 2003. Genetic structure

736 in otter (Lutra lutra) populations in Europe: implications for conservation. In: Animal

737 Conservation forum. Cambridge University Press, 93-100.

738 
739 Remonti L, Prigioni C, Balestrieri A, Sgrosso S, Priore G. 2008. Trophic flexibility of the otter

740 (Lutra lutra) in southern Italy. Mammalian Biology 73: 293-302. DOI:

$741 \quad$ 10.1016/j.mambio.2007.04.004

742

743 Romano A, Bartolomei R, Conte A, Fulco E. 2012. Amphibians in Southern Apennine:

744 distribution, ecology and conservation notes in the "Appennino Lucano, Val d'Agri e

745 Lagonegrese” National Park (Southern Italy). Acta Herpetologica 7:203-219. DOI:

$746 \quad 10.13128 /$ Acta_Herpetol-10503.

747

748

749

750

751

752

753

754

755

756

757

758

759

760

Rondinini C, Battistoni A, Peronace V, Teofili C. 2013. Lista Rossa IUCN dei Vertebrati Italiani. Comitato Italiano IUCN e Ministero dell'Ambiente e dela Tutela del Territorio e del Mare, Roma.

Ruiz-Olmo J, Lafontaine L, Prigioni C, López-Martin JM, Santos-Reis M. 2002. Pollution and its effects on otter populations in South-Western Europe. In: Conroy CVH, Yoxon P, Gutleb AC, ed. Proceedings of the First Otter Toxicology Conference. International Otter Survival Fund, Broadford: Scotland, 63-82.

Reyjol Y, Hugueny B, Bianco PG, Didier P. 2008. Congruence between riverine fish species richness and endemism at the biogeographical scale: the role of history. Aquatic Conserv: Mar. Freshw. Ecosyst. DOI: 10.1002/aqc.938. 
761 Sanderson EW, Redford KH, Vedder A, Coppolillo PB, Ward SE. 2002. A conceptual model for

762 conservation planning based on landscape species requirements. Landscape and urban planning

763 58:41-56. DOI: https://doi.org/10.1016/S0169-2046(01)00231-6.

764

765 Scorpio V, Loya A, Di Febbraro M, Rizzo A, Aucelli P. 2014. Hydromorphology meets mammal

766 ecology: river morphological quality, recent channel adjustments and otter resilience. River

767 Research and Applications 32:267-279 DOI: 10.1002/rra.2848.

768

769

Smiroldo G, Balestrieri A, Remonti L, Prigioni C. 2009. Seasonal and habitat-related variation of 770 otter Lutra lutra diet in a Mediterranean river catchment (Italy). Folia Zoologica-Praha 58: 87.

Soininen EM Valentini A, Coissac E, Miquel C, Gielly L, Brochmann C, Brysting AK, Sønstebø JH, Ims RA, Yoccoz NG, Taberlet. 2009. Analysing diet of small herbivores: the efficiency of DNA barcoding coupled with high-throughput pyrosequencing for deciphering the composition of complex plant mixtures. Frontiers in Zoology. 6:16. DOI: https://doi.org/10.1186/1742-99946-16.

777 Natura, pp. 236-237, Min. Ambiente - Ist. Naz. Fauna Selvatica. 
781 Taberlet P, Griffin S, Goossens B, Questiau S, Manceau V, Escaravage N, Waits LP, Bouvet J.

782 1996. Reliable genotyping of samples with very low DNA quantities using PCR. Nucleic Acids

783 Research 24:3189-3194. DOI: https://doi.org/10.1093/nar/24.16.3189.

784

785 Taylor PG. 1996. Reproducibility of ancient DNA sequences from extinct Pleistocene fauna.

786 Molecular Biology and Evolution 13:283-285. DOI:

787 https://doi.org/10.1093/oxfordjournals.molbev.a025566.

788

789 Thuiller W, Lavergne S, Roquet C, Boulangeat I, Lafourcade B, Araujo MB. 2011.

790 Consequences of climate change on the tree of life in Europe. Nature 470:531-534. DOI:

791 https://doi.org/10.1038/nature09705.

792

793 Valentini A, Pompanon F, Taberlet P. 2009. DNA barcoding for ecologists. Trends in ecology

794 and evolution 24: 110-117. DOI: https://doi.org/10.1016/j.tree.2008.09.011.

795

796 Voicu R, Radecki-Pawlik A, Tymiński T, Mokwa M, Sotir R, Voicu L. 2020. A potential 797 engineering solution to facilitate upstream movement of fish in mountain rivers with weirs:

798 Southern Carpathians, the Azuga River. Journal of Mountain Science 17:501-515 DOI:

799 https://doi.org/10.1007/s11629-019-5572-y.

800 
801 Vynne C, Baker MR, Breuer ZK, Wasser SK. 2012. Factors influencing degradation of DNA and 802 hormones in maned wolf scat. Animal Conservation 15:184-194. DOI:

803 https://doi.org/10.1111/j.1469-1795.2011.00503.x.

804

805 Wasser SK, Houston CS, Koehler GM, Cadd GG, Fain SR. 1997. Techniques for application of 806 faecal DNA methods to field studies of Ursids. Molecular Ecology 6:1091-1097. DOI:

807 10.1046/j.1365-294x.1997.00281.x

808

809 Zarzoso-Lacoste D, Bonnaud E, Corse E, Gilles A, Meglecz E, Costedoat C, Gouni A, Vidal E.

810 2016. Improving morphological diet studies with molecular ecology: An application for invasive

811 mammal predation on island birds. Biological Conservation 193:134-142. DOI:

812 https://doi.org/10.1016/j.biocon.2015.11.018. 


\section{Figure 1}

Study area

Location of collected samples (red spots), grouped in 5 pools. The blue lines highlight the main rivers (order 1 ) and their tributaries (order 2, 3 and 4 according to waterway hierarchy). The dashed red lines represent regional boundaries. In the inset, the current otter distribution (inferred from Loy et al., 2015) is reported in orange and the study area is defined by the black rectangle.

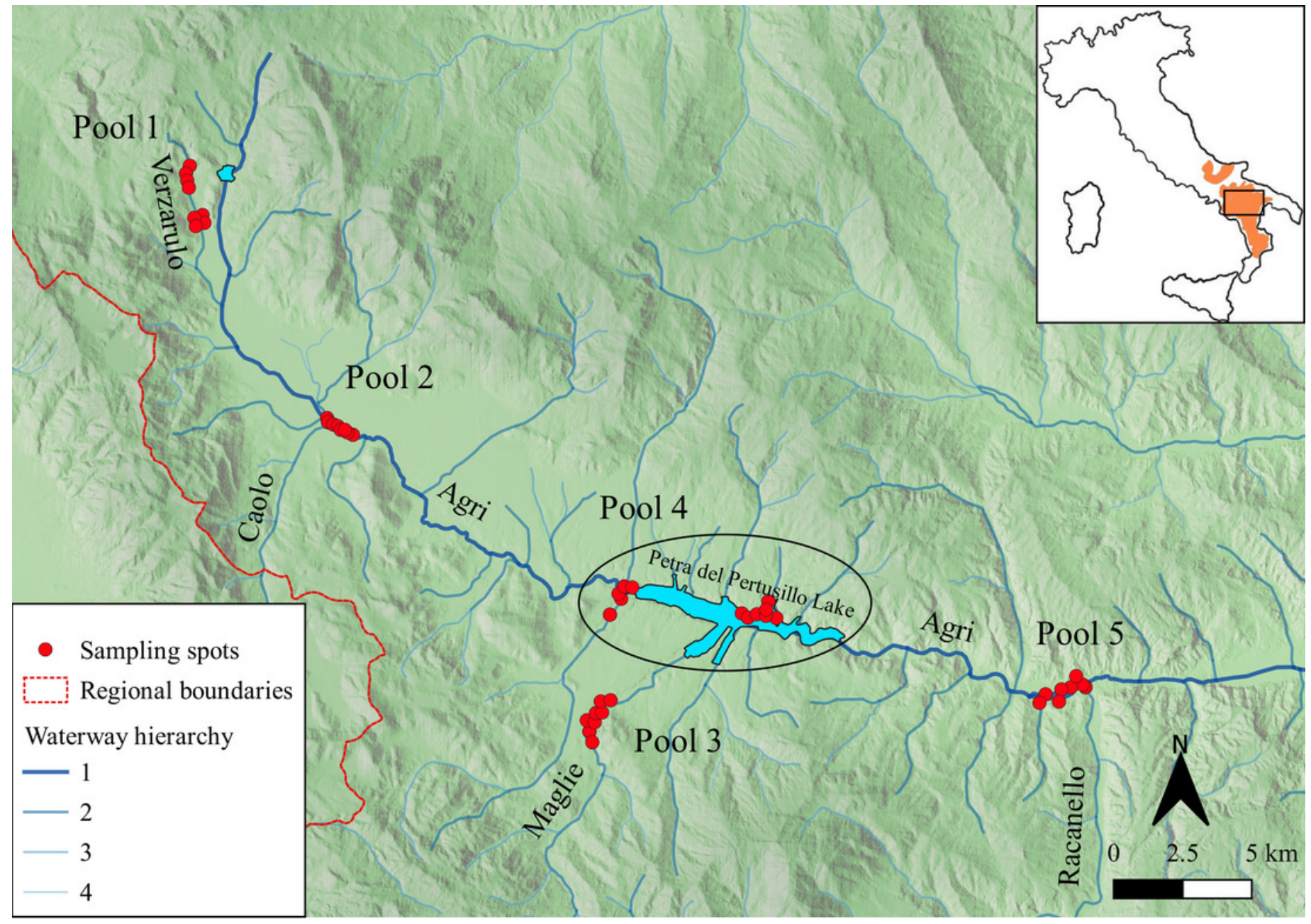




\section{Figure 2}

Diet of all otter samples analyzed

A) Number of reads count $\left(\log _{10}\right)$, from all 5 pools, assigned to each family. Blue, Cyprinidae;

pink, Percidae; green, Ranidae; orange, Salmonidae; red, Bufonidae; yellow, Gobidae. B) Boxplot showing the Relative Read Abundance $\left(\log _{10}\right)$ of the most represented fish and amphibian taxa revealed in the diet of otters. The histogram represents the interquartile range with the median (bold black line), the outliers (empty circles), the whiskers (dashed vertical lines) and the minimum and maximum (horizontal lines). Blue, Cyprinidae; pink, Percidae; green, Ranidae; orange, Salmonidae. 


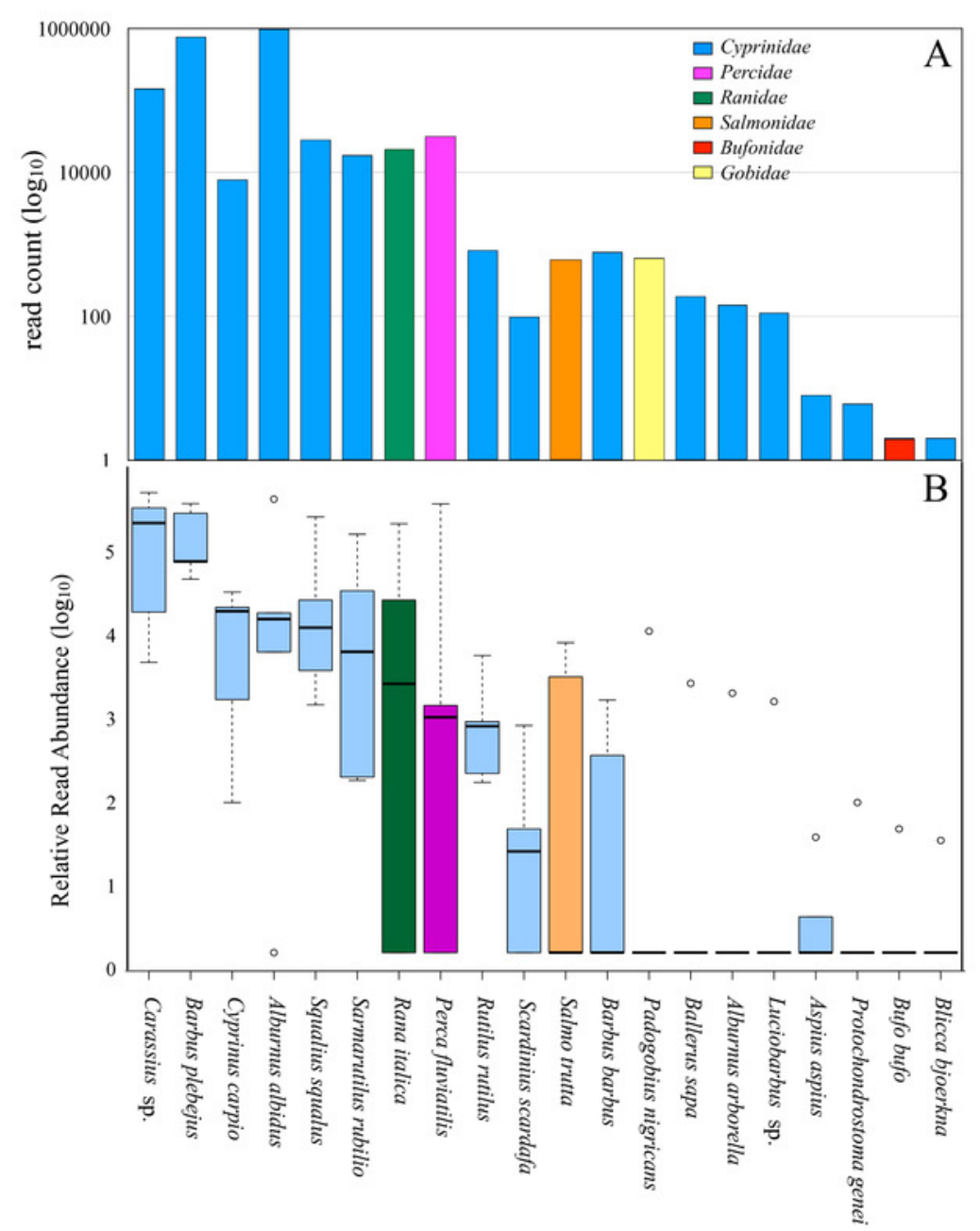




\section{Figure 3}

Variation of otter diet diversity and relatedness in the 5 types of watercourses

A) Fish families found in each river type, the pie diagrams show the taxonomic composition of the otters' diet at family level. For each pool are indicated the richness (S) and ShannonWeaver Index $(\mathrm{H})$, the differences among indices are significant (Chi-square value: 958.4, degrees of freedom: 40, $p<0.05)$. Blue, Cyprinidae; pink, Percidae; green, Ranidae; orange, Salmonidae; red, Bufonidae; yellow, Gobidae. B) Correspondence Analysis (CA) comparing the diet composition of the 5 pools (object) using fish taxa (variables). Others represent Luciobarbus sp., Ballerus sapa, Blicca bjoerkna, Protochondrostoma genei and Alburnus alborella. In the inset eigenvalues (\% of the total) are reported. 

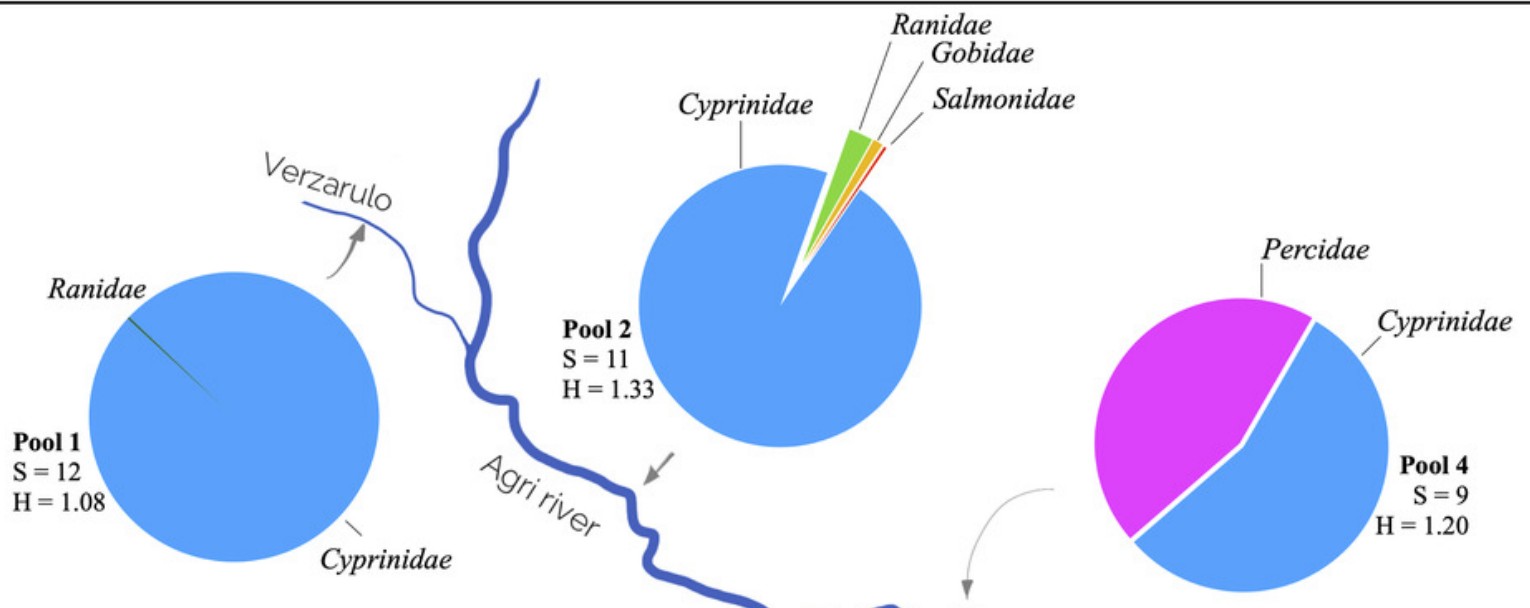

A
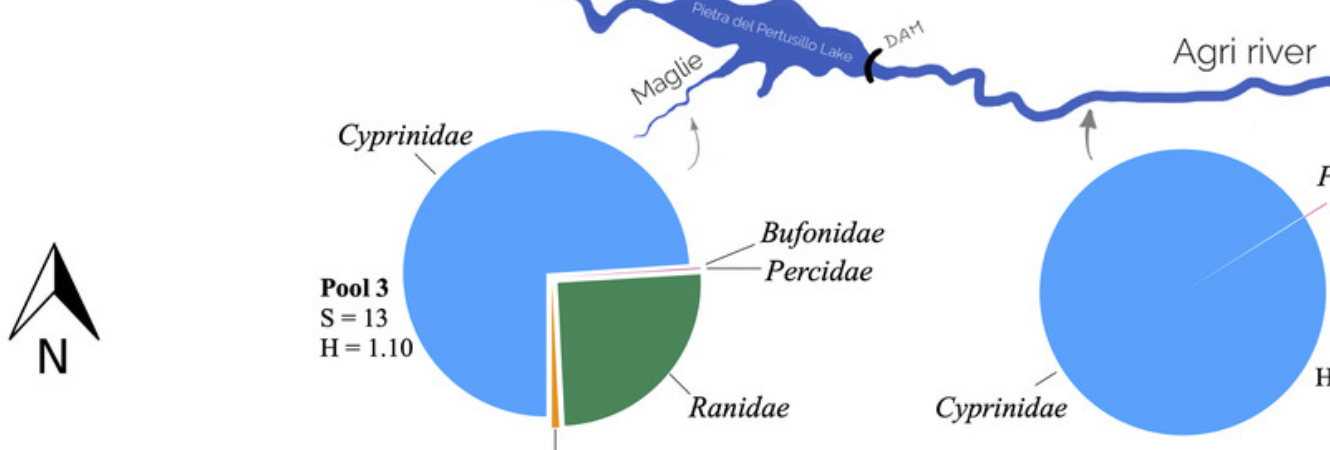

Percidae

Pool 5

$\mathrm{S}=16$

$\mathrm{H}=1.30$

Salmonidae
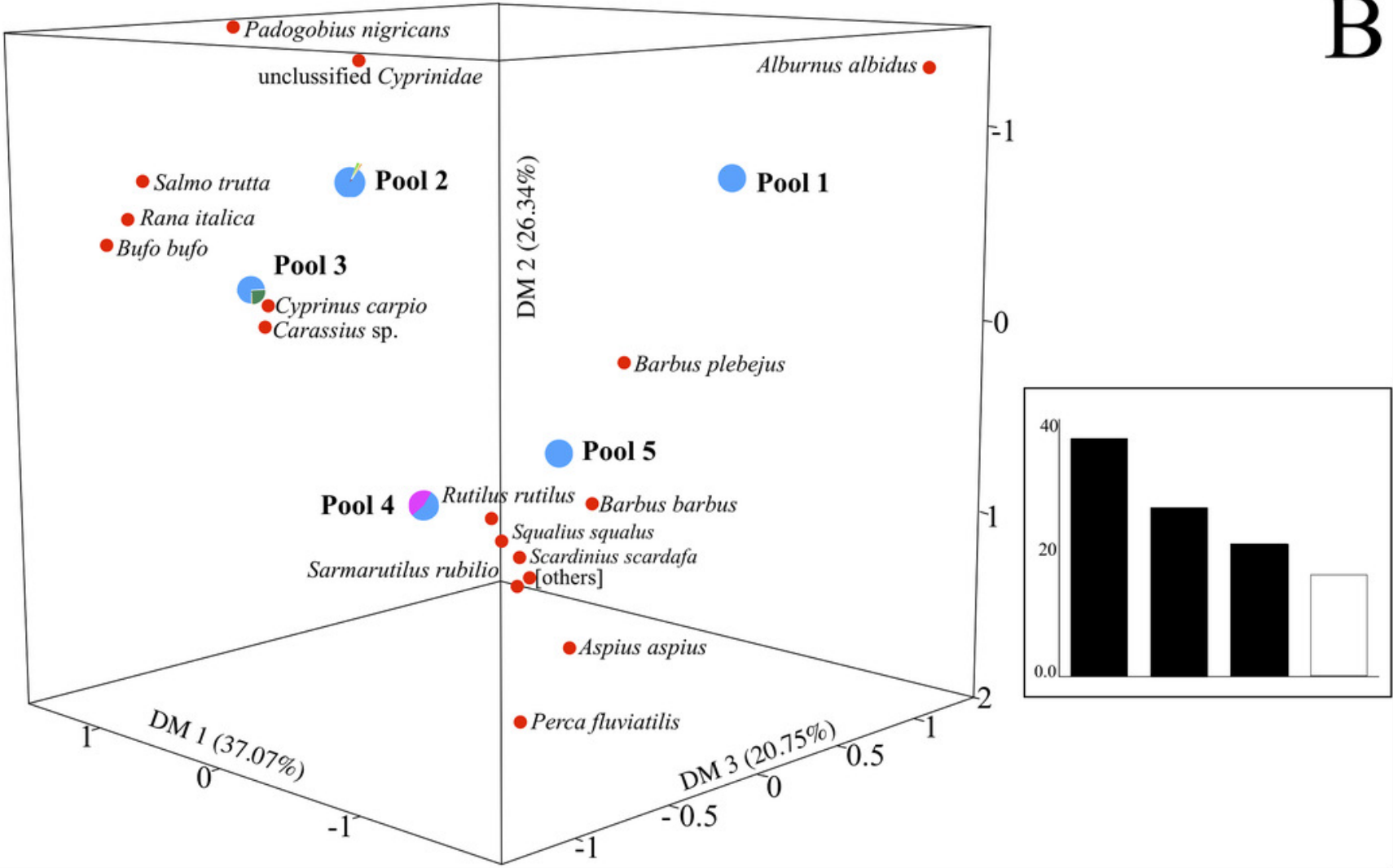


\section{Table $\mathbf{1}$ (on next page)}

Data processing

Details of bioinformatic data processing from High Throughput Sequencing on Illumina MiSeq platform of DNA extracted from otter spraints. Quality control (QC); read Forward (read F); Read reverse (read R); Chromosome (Chr); map quality (mapQ). 


\begin{tabular}{|c|c|c|c|c|c|}
\hline $\begin{array}{l}\text { in total (QC-passed } \\
\text { reads + QC-failed } \\
\text { reads) }\end{array}$ & $2503050+0$ & $700288+0$ & $1146568+0$ & $716801+0$ & $1931112+0$ \\
\hline secondary & $0+0$ & $0+0$ & $0+0$ & $0+0$ & $0+0$ \\
\hline supplementary & $15616+0$ & $12194+0$ & $90332+0$ & $148249+0$ & $13590+0$ \\
\hline duplicates & $0+0$ & $0+0$ & $0+0$ & $0+0$ & $0+0$ \\
\hline mapped & $\begin{array}{l}2482444+0(99.18 \%: \\
\text { N/A })\end{array}$ & $\begin{array}{l}683815+0(97.65 \%: \\
N / A)\end{array}$ & $\begin{array}{l}1134865+0(98.98 \%: \\
\text { N/A })\end{array}$ & $\begin{array}{l}702198+0(97.96 \%: \\
\text { N/A })\end{array}$ & $\begin{array}{l}1905046+0(98.65 \%: \\
\text { N/A })\end{array}$ \\
\hline paired in sequencing & $2487434+0$ & $688094+0$ & $1056236+0$ & $568552+0$ & $1917522+0$ \\
\hline $\operatorname{read} F$ & $1243717+0$ & $344047+0$ & $528118+0$ & $284276+0$ & $958761+0$ \\
\hline $\operatorname{read} \mathbf{R}$ & $1243717+0$ & $344047+0$ & $528118+0$ & $284276+0$ & $958761+0$ \\
\hline properly paired & $\begin{array}{l}2180922+0(87.68 \%: \\
\text { N/A })\end{array}$ & $294+0(0.04 \%: \mathrm{N} / \mathrm{A})$ & $\begin{array}{l}39188+0(3.71 \%: \\
\text { N/A) }\end{array}$ & $\begin{array}{l}23656+0(4.16 \%: \\
\text { N/A })\end{array}$ & $530+0(0.03 \%: \mathrm{N} / \mathrm{A})$ \\
\hline $\begin{array}{l}\text { with itself and mate } \\
\text { mapped }\end{array}$ & $2446254+0$ & $655200+0$ & $1032912+0$ & $539538+0$ & $1865562+0$ \\
\hline singletons & $\begin{array}{l}20574+0(0.83 \%: \\
\text { N/A })\end{array}$ & $\begin{array}{l}16421+0(2.39 \%: \\
\mathrm{N} / \mathrm{A})\end{array}$ & $\begin{array}{l}11621+0(1.10 \%: \\
\text { N/A })\end{array}$ & $\begin{array}{l}14411+0(2.53 \%: \\
\text { N/A })\end{array}$ & $\begin{array}{l}25894+0(1.35 \%: \\
\text { N/A })\end{array}$ \\
\hline $\begin{array}{l}\text { with mate mapped to } \\
\text { a different chr }\end{array}$ & $265330+0$ & $556252+0$ & $931324+0$ & $445678+0$ & $1732242+0$ \\
\hline $\begin{array}{l}\text { with mate mapped to } \\
\text { a different chr } \\
(\text { mapQ }>=5)\end{array}$ & $49779+0$ & $28183+0$ & $40633+0$ & $42070+0$ & $36160+0$ \\
\hline
\end{tabular}


Table 2 (on next page)

Details of the otter's diet

Qualitative (Family and genus/species) and quantitative (Percent of Occurrence \%) analysis of otter diet. 


\begin{tabular}{|c|c|c|c|c|c|c|c|}
\hline & \multirow[t]{2}{*}{ Family } & \multirow[t]{2}{*}{ Genus/Species } & \multicolumn{5}{|c|}{ Percent of occurrence $(\%)$} \\
\hline & & & Pool 1 & Pool 2 & Pool 3 & Pool 4 & Pool 5 \\
\hline & Cyprinidae & Carassius sp. & 1.9386 & 25.6767 & 62.0621 & 39.7780 & 0.4517 \\
\hline & Cyprinidae & Barbus plebejus & 34.0436 & 8.4140 & 5.0461 & 8.2649 & 45.0129 \\
\hline & Cyprinidae & Cyprinus carpio & 0.1538 & 1.9892 & 3.4597 & 2.2342 & 0.0078 \\
\hline & Cyprinidae & Alburnus albidus & 51.2940 & 1.5838 & 0.6100 & 0.0000 & 1.9001 \\
\hline & Cyprinidae & Squalius squalus & 0.1319 & 2.7483 & 0.3560 & 1.2348 & 30.6459 \\
\hline & Cyprinidae & Sarmarutilus rubilio & 0.0148 & 0.6142 & 0.0162 & 3.5938 & 18.5180 \\
\hline & Ranidae & Rana italica & 0.2424 & 2.7500 & 25.1475 & 0.0000 & 0.0000 \\
\hline & Percidae & Perca fluviatilis & 0.0000 & 0.0000 & 0.0920 & 44.7242 & 0.1294 \\
\hline & Cyprinidae & Rutilus rutilus & 0.0139 & 0.0811 & 0.0180 & 0.0709 & 0.5514 \\
\hline & Cyprinidae & Scardinius scardafa & 0.0019 & 0.0000 & 0.0036 & 0.0000 & 0.0725 \\
\hline & Salmonidae & Salmo trutta & 0.0000 & 0.2967 & 0.7995 & 0.0000 & 0.0000 \\
\hline & Cyprinidae & Barbus barbus & 0.0304 & 0.0000 & 0.0000 & 0.0000 & 0.1514 \\
\hline & Cyprinidae & Protochondrostoma genei & 0.0000 & 0.0000 & 0.0000 & 0.0000 & 0.0078 \\
\hline & Cyprinidae & Ballerus sapa & 0.0000 & 0.0000 & 0.0000 & 0.0000 & 0.2459 \\
\hline & Cyprinidae & Alburnus arborella & 0.0000 & 0.0000 & 0.0000 & 0.0000 & 0.1851 \\
\hline & Cyprinidae & Luciobarbus sp. & 0.0000 & 0.0000 & 0.0000 & 0.0000 & 0.1450 \\
\hline & Cyprinidae & Aspius aspius & 0.0003 & 0.0000 & 0.0000 & 0.0028 & 0.0000 \\
\hline & Gobidae & Padogobius nigricans & 0.0000 & 1.1145 & 0.0000 & 0.0000 & 0.0000 \\
\hline & Bufonidae & Bufo bufo & 0.0000 & 0.0000 & 0.0036 & 0.0000 & 0.0000 \\
\hline & Cyprinidae & Blicca bjoerkna & 0.0000 & 0.0000 & 0.0000 & 0.0000 & 0.0026 \\
\hline & Cyprinidae & unclussified Cyprinidae & 12.1350 & 54.7315 & 2.3859 & 0.1248 & 1.9726 \\
\hline Total & 6 & 21 & 100 & 100 & 100 & 100 & 100 \\
\hline
\end{tabular}

